\title{
25. BORON GEOCHEMISTRY AT THE MIOCENE/PLIOCENE BOUNDARY
}

\author{
N. Coradossi and E. Corazza, Istituto di Mineralogia, Petrografia e Geochimica, \\ Via Lamarmora, 4, 50121 Firenze, Italy
}

\begin{abstract}
We analyzed 20 DSDP samples obtained from the Miocene/Pliocene boundary at Site 397 of Leg $47 \mathrm{~A}$. These samples were analyzed for water loss at $40^{\circ} \mathrm{C}$ and at $110^{\circ} \mathrm{C}$, for loss upon attack by $0.1 N \mathrm{HCl}$, for clay content $(<2 \mu \mathrm{m})$, and for boron (B) in both the bulk sediment and the clay fraction. Water content was found to decrease slightly with depth due to compaction. Calcite was found to be the main constituent of the sediments $(63 \%$ average) which also contain dolomite, pyrite, and organic matter. The clay fraction is complementary to calcite and correlates closely with total B concentration. Boron in the clay fraction is constant and close to values calculated from the $\mathrm{B} /$ clay ratio. Boron shows values typical of open-sea sediments ( $127 \mathrm{ppm}$ average). Its behavior indicates that it is concentrated in the clay fraction. A sharp variation in the carbonate and clay content was found at the TortonianMessinian boundary (not at the Messinian-Zanclean).
\end{abstract}

\section{INTRODUCTION}

The geochemistry of boron in sediments is strongly affected by the clay minerals, namely illite, as well as by water salinity. This "capture" of boron by clay minerals has been extensively described by several authors (Hingston, 1964; Fleet, 1965; Lerman, 1966; Levinson and Ludwick, 1966; Thompson, 1968; Landergreen and Carvajal, 1969; Couch, 1971; Walker, 1975). From these studies, a remarkable difference is evident between clays sedimented in opensea and continental environments.

A study of Messinian clay sediments from Sicily has given indications of environment changes relative to evaporitic events (Coradossi and Corazza, in press). The results obtained encouraged the authors to extend this study to DSDP cores at the Miocene/Pliocene boundary. Site 397 was considered particularly useful for evaluating the influence of the Mediterranen salinity crisis on the adjoining oceanic basins, even though no particular variations were expected in the boron distribution, the environment probably having always been one of typical open-sea conditions.

This paper provides preliminary results of boron concentrations relative to grain-size distribution. A later paper will deal with the geochemistry of other elements suitable as facies indicators; namely, the metallic elements $\mathrm{V}, \mathrm{Cu}, \mathrm{Zn}, \mathrm{Ni}$, and $\mathrm{Co}$.

\section{EXPERIMENTAL PROCEDURE}

We examined 20 samples, each approximately $2 \mathrm{~cm}$ thick, from the tops of Cores 397-34 to 55. The analytical results are summarized in Table 1.

The sediments, which had a muddy consistency, underwent preliminary drying at $40^{\circ} \mathrm{C}$ until constant weight. This yielded a standardization for all samples and provided a weight loss for water. Further drying (at $110^{\circ} \mathrm{C}$ until constant weight) yielded an insignificant water loss of 0.9 per cent on the average. Therefore, all determinations reported in this paper refer to the sample dried at $40^{\circ} \mathrm{C}$.

The samples were examined qualitatively by X-ray powder diffraction. From this, calcite was determined to be the dominant mineral except in Sample 397-54-1, $5 \mathrm{~cm}$. The other minerals showed only minor differences in their relative concentrations. The clay fraction was not analyzed for individual minerals. Pyrite was commonly observed, sometimes in nodules, in nearly all samples. Organic matter was always present.

Boron concentrations in bulk sediment were determined by optical emission spectrography following the procedure of Coradossi and Corazza (in press).

The high calcite content in all samples required acid removal before the size separations were carried out. Digestion was done by means of $0.1 N \mathrm{HCl}$ at room temperature with $\mathrm{pH}$ control. The residue was then centrifuged and rinsed until the acid reaction ceased, which coincided with the disappearance of chlorides. The present results by $\mathrm{HCl}$ loss are in good agreement with the values found by Cita (this volume) through calcimetry analysis.

From the acid residue, the $<2 \mu \mathrm{m}$ fraction (hereafter referred to as clay) was separated by means of conventional sedimentation analysis based on settling velocity. The $>2 \mu \mathrm{m}$ fraction also was analyzed for B content with optical emission spectrography.

\section{RESULTS AND DISCUSSION}

The results listed in Table 1 provide general information on the mineralogical character of the sediments and the boron distribution.

Based on preliminary X-ray analysis, the sediments were classified as marly chalks containing appreciable amounts of pyrite and amorphous materials. Calcite is 
TABLE 1

Analytical Results of Samples From Site 397, Leg 47A

\begin{tabular}{|c|c|c|c|c|c|c|c|c|c|}
\hline $\begin{array}{c}\text { Sample } \\
\text { (Interval in } \mathrm{cm} \text { ) }\end{array}$ & $\begin{array}{l}\text { Sub-Bottom } \\
\text { Depth } \\
\text { (m) }\end{array}$ & $\begin{array}{l}\text { Water Loss } \\
\text { at } 40^{\circ} \mathrm{C} \\
(\%)\end{array}$ & $\begin{array}{l}\text { Water Loss } \\
\text { at } 110^{\circ} \mathrm{C} \\
(\%)\end{array}$ & $\begin{array}{l}0.1 N \mathrm{HCl} \\
\text { Loss } \\
(\%)\end{array}$ & $\begin{array}{c}\text { Clay Fraction } \\
<2 \mu \mathrm{m} \\
(\%)\end{array}$ & $\begin{array}{l}\text { B in the Bulk } \\
\text { Sediment } \\
\text { (ppm) }\end{array}$ & $\begin{array}{l}\text { B in the Clay } \\
\text { Fraction } \\
\text { (ppm) }\end{array}$ & $\begin{array}{l}B_{\text {calc. }} \\
\text { (ppm) }\end{array}$ & Age \\
\hline $34-1,8$ & 313.08 & 28 & 29 & 56 & 42 & 56 & 139 & 133 & \\
\hline $35-1,8$ & 322.58 & 30 & 30 & 58 & 26 & 54 & 111 & 208 & \\
\hline $36-1,10$ & 332.10 & 31 & 31 & 67 & 18 & 21 & 113 & 117 & $=$ \\
\hline $37-1,10$ & 341.60 & 32 & 32 & 65 & 13 & 29 & 125 & 223 & తై \\
\hline $38-1,8$ & 351.08 & 34 & 34 & 62 & 18 & 20 & 105 & 111 & एँ \\
\hline $39-1,10$ & 360.60 & 31 & 31 & 74 & 13 & 33 & 131 & 254 & สี้ \\
\hline $40-1,20$ & 370.20 & 33 & 34 & 52 & 18 & 41 & 113 & 228 & \\
\hline $41-1,6$ & 379.56 & 32 & 32 & 75 & 15 & 19 & 137 & 127 & \\
\hline $42-1,85$ & 389.85 & 26 & 26 & 76 & 14 & 17 & 127 & 121 & \\
\hline $43-1,8$ & 398.58 & 28 & 33 & 75 & 15 & 17 & 133 & 113 & \\
\hline $44-1,8$ & 408.08 & 28 & 29 & 75 & 16 & 24 & 146 & 185 & .ే \\
\hline $45-1,8$ & 419.58 & 25 & 26 & 71 & 18 & 23 & 141 & 128 & 点 \\
\hline $47-1,20$ & 436.70 & 28 & 28 & 77 & 16 & 25 & 147 & 156 & $\stackrel{\infty}{\infty}$ \\
\hline $48-1,20$ & 446.20 & 27 & 28 & 75 & 16 & 19 & 122 & 119 & $z$ \\
\hline $49-1,5$ & 455.55 & 21 & 22 & 56 & 27 & 39 & 108 & 144 & \\
\hline $50-1,40$ & 465.40 & 22 & 23 & 60 & 16 & 33 & 137 & 206 & \\
\hline $52-1,5$ & 493.55 & 24 & 25 & 58 & 38 & 46 & 139 & 121 & ב \\
\hline $53-1,25$ & 503.25 & 16 & 17 & 61 & 12 & 48 & 122 & 400 & ప్ \\
\hline $54-1,5$ & 512.55 & 17 & 18 & 25 & 61 & 81 & 122 & 133 & ठั \\
\hline $55-1,5$ & 522.05 & 18 & 19 & 41 & 31 & 78 & 128 & 252 & \\
\hline
\end{tabular}

by far the prevailing carbonate (traces of dolomite); among the clay minerals, smectites are very common together with kaolinite and illite.

\section{Water Content}

The water loss at $40^{\circ} \mathrm{C}$ shows constant values near the average value of 27 per cent. A trend of decreasing water loss can be noticed in the deeper samples. This water content decrease is ascribed to sediment compaction. The water loss at $110^{\circ} \mathrm{C}$ is nearly the same as the $40^{\circ} \mathrm{C}$ loss, indicating that all or almost all the water in the sediment is pore water.

\section{Carbonates}

Treatment with dilute hydrochloric acid, which was necessary to avoid clay minerals alteration, dissolved only calcium carbonates (which are represented almost entirely by calcite). The weight of the acid residue reflected the carbonate content (i.e., calcite), which averaged 63 per cent. No allowance was made for more acid-resistant carbonates such as dolomite.

The general trend for carbonate content is that there are identical and constant values for both Messinian and Zanclean sediments (averaging 68\%). A decrease in carbonate content is observed in the Tortonian (50\% average), as also pointed out by Cita (this volume). The uppermost two samples show a low carbonate content which does not correlate with any age interval.

\section{Clay Fraction}

The majority of samples (14) have a clay content below the average value of 22 per cent, and have a high carbonate content. Only Sample 397-54-1, $5 \mathrm{~cm}$ shows a dominance of clay minerals (and, conversely, a low carbonate content). The sum of the carbonate plus the clay fraction averages 85 per cent.

\section{Boron}

The average bulk boron content is $36 \mathrm{ppm}$. The bulk boron concentration shows wide variations with the same trends as for clay content; namely, high concentrations in the Tortonian samples as well as in Cores 397-34 and 35. The evident correlation between bulk boron concentration and the clay content implies a relatively constant boron content in the latter. The values of $\mathrm{B}_{\text {calc. }}$ given in Table 1 were inferred by attributing the total $\mathrm{B}$ contribution to the clay fraction, and were calculated as the ratio bulk B/clay fraction. In spite of some wide variations, most B values are close to the average of $174 \mathrm{ppm}$. The boron concentration in the clay fraction shows no appreciable variation from an average of $127 \mathrm{ppm}$, nor any trend in a downhole direction. The concentrations are typical of marine clays and their constancy is an index of the equilibrium between clay minerals and sea water.

While a geologic event like the Tortonian-Messinian transition evidently influenced biological activity and sedimentation (both qualitatively and quantitatively), it apparently did not influence the chemical and physical equilibria of the reactions between clay minerals and boron in the ocean environment.

The average boron concentrations measured in the clay fraction are comparable to the $\mathrm{B}_{\text {calc }}$ values, 127 versus $174 \mathrm{ppm} \mathrm{B}$, respectively. Some discrepancies can be attributed to errors in the clay fraction determinations. This agreement leads to the conclusion that all boron in the sediment is quantitatively concentrated by the clay fraction, which also includes most of the organic matter. The latter is known to absorb B from sea water; however, no attempt was made to differentiate it from clay minerals. 


\section{ACKNOWLEDGMENTS}

This work was partially supported by the Italian Consiglio Nazionale delle Ricerche. Many thanks are due to Prof. F. Barberi, University of Pisa, Italy, for reviewing the paper and for stimulating discussions.

\section{REFERENCES}

Coradossi, N. and Corazza, E., in press. Geochemistry of Messinian clay sediments from Sicily: a preliminary investigation, Mem. Soc. Geol. Ital., v. 16.

Couch, E. L., 1971. Calculation of paleosalinities from Boron and clay mineral data, Am. Assoc. Petroleum Geologists Bull., v. 55, p. 1829.

Fleet, M. E. L., 1965. Preliminary investigations into the sorption of boron by clay minerals, Clay Minerals Bull., v. 6, p. 3 .
Hingston, F. J., 1964. Reaction between boron and clays, Australian J. Soil Res., v. 2, p. 83.

Landergreen, S. and Carvajal, M. C., 1969. Contribution to the geochemistry of boron, Arkiv. Min. Geol., v. 5, p. 11.

Lerman, A., 1966. Boron in clays and estimation of paleosalinities, Sedimentology, v. 6, p. 267.

Levinson, A. A. and Ludwick, J. C., 1966. Speculation on the incorporation of B into argillaceous sediments, Geochim. Cosmochim. Acta, v. 30, p. 855.

Thompson, G., 1968. Analyses of B, Ga, Rb, and K in two deep-sea sediment cores; consideration of their use as paleoenvironmental indicators, Marine Geol., v. 6, p. 463.

Walker, C. T., 1975. Geochemistry of boron: Stroudsburg, Pennsylvania (Dowden, Hutchinson \& Ross, Inc.). 